\title{
Governance, Corruption, and the Informal Economy
}

\author{
Idrissa M. Ouédraogo \\ Economics Department, University Ouaga II, Ouagadougou, Burkina Faso \\ Email: idriss_mo@yahoo.fr
}

How to cite this paper: Ouédraogo, I.M. (2017) Governance, Corruption, and the Informal Economy. Modern Economy, 8, 256-271.

https://doi.org/10.4236/me.2017.82018

Received: January 23, 2017

Accepted: February 21, 2017

Published: February 24, 2017

Copyright $\odot 2017$ by author and Scientific Research Publishing Inc. This work is licensed under the Creative Commons Attribution International License (CC BY 4.0).

http://creativecommons.org/licenses/by/4.0/

\section{(c) (i) Open Access}

\begin{abstract}
This paper uses data from 23 Sub-Saharan countries to analyze the relationship between governance, corruption, and the size of the informal economy. The results show that corruption, the quality of governance, the quality of institutional settings, and the unemployment rates are major determinants of the size of the informal economy. More specifically, it is found that a high level of corruption and poor institutional settings favor an increase of the informal economy. The unemployment rate is negatively related to the size of the informal economy, and greater fiscal freedom and business freedom are associated with a larger informal economy, while monetary freedom reduces the size of the informal sector.
\end{abstract}

\section{Keywords}

Informal Economy, Corruption, Governance, Sub-Saharan Africa

\section{Introduction}

Since the concept of the informal sector was first used during the 1970s, it has been admitted that the so-called informal activities in developing countries constitute a major source of employment for those rural immigrants and urban dwellers who were seeking employment in the formal sector and were unable to find any. The relative importance of the informal sector for employment varies by country, varying from $20 \%$ to $60 \%$ of urban employment ${ }^{1}$.

The informal sector refers to all activities producing goods or services that are unregulated and hardly fit into any of the conventional economic categories. Activities viewed as part of the informal sector range from fringe and survival

${ }^{1}$ The informal sector has also been called the informal economy, unofficial economy, underground economy, parallel economy, or hidden economy. These terms will be used interchangeably in the rest of the paper. 
strategies (e.g., street vending, letter writing, and shoe shining) to more organized operating units (e.g., small artisans, mechanics, and carpenters). At the 90th Session of the International Labour Conference in 2002, the ILO launched the concept of "informal economy" that attempts to incorporate in the definition other forms of informal employment that were not considered in the notion of the "informal sector". The term informal economy not only includes activities of the "informal sector" (casual and survival-type activities), but also accounts for new types of informal activities that have been emerging in industrialized, transition and developing economies and being operated beyond the law. They include home working and workers in sweatshops and self-employed in microenterprises.

The informal economy is a specific sphere of economic activity that has emerged in developing countries and represents a significant part of the economies of these countries. Indeed, the importance of the informal economy has been largely demonstrated, especially for developing and emerging countries where rule of law and institutions fail to ensure the efficient functioning of the market [1]. For [2], the informal economy includes both the production activities of unofficially registered firms and the undeclared products of formally registered firms, which reflects the rather broad scope of this concept of an underground economy. This type of economy is supposed to operate in a clandestine manner, but in developing countries it is carried out under the gaze of the authorities who even seek ways and means to develop it.

Although the informal sector has long been perceived as a phenomenon with adverse effects, nowadays, it is widely accepted that this sector is an important component of the economy, both in terms of employment and wealth creation. The tendency now is to promote and expand it wherever possible. Policymakers and development agencies tend to give a central role to the informal sector in development strategies, realizing that any development program that does not properly consider the informal sector will likely fail to promote economic progress.

Several factors have been identified in the literature as causes of the emergence of the informal economy. These include the tax burden, the unemployment rate and labor regulations, and the quality of institutions. Among the driving factors of the informal economy, corruption and the quality of governance have been the subjects of abundant analyses [3]-[10]. The relationship between corruption and the informal economy is theoretically ambiguous. While [3] and [5] suggested a positive relationship between corruption and the underground economy, [8] found that corruption is negatively related to the informal economy. Although acknowledging that the relationship between the quality of institutions and corruption is ambiguous, [9] stated that the shadow economy and corruption are substitutes. More specifically, [10] argued that the sense of the relationship between the two variables depends not only on the type of index of corruption used but also on the level of development.

Considering these discussions and the ambiguities raised, it remains impor- 
tant to analyze the behavior of the informal economy in Sub-Saharan Africa (SSA), especially as it relates to corruption and the quality of the institutional setting and its determinants in this space. There has been very little analysis of the relationship between corruption, the quality of governance, and the informal sector in SSA. Yet, this type of analysis is important for countries with a high level of corruption and governance failures and where the informal sector matters. Such analysis not only furthers our understanding of the informal economy but is also of policy relevance. Knowing the factors that drive agents to operate their businesses beyond state regulation can help to formulate policies to recommend. This study fills this gap. Its objective is to find the determinants of the informal economy in SSA. Data for 23 SSA countries over the period from 2000 to 2010 are used to empirically analyze the relationship between corruption and the size of the shadow economy.

This paper is organized as follows. Section 2 provides some insight on the relationship between governance, corruption, and the informal economy that has been prevailing in the literature. Section 3 outlines the methodology used in the study. Subsequently, Section 4 presents the empirical results of the research, and the last section concludes the study.

\section{The Nexus between Institutions, Corruption and the Informal Economy: Complementarity or Substitutability?}

The relationship between corruption and the institutional arrangements of countries seems to be well documented and obvious. Indeed, [11] found that corruption, which is generally defined as the abuse of public power for private gain, reflects a deficiency in political and administrative systems and its persistence is linked to the failure of the judicial system and rules of law. Thus, the existence of corruption implies a weakness of governance in general. In this sense, one can agree with [12] that corruption reflects the lack of effectiveness of governance and even alters this effectiveness. Regarding the links between corruption and the informal economy, the literature reveals two types of relationships between these two entities. Corruption and the informal economy are either complements or substitutes [11].

Several authors, including [3] [6] [10] [11] and [5], highlighted the idea that corruption and the informal economy are complementary (i.e., there is a positive relationship between them). These authors are part of a more global approach that considers the burden of institutions and the cost of complying with all mandatory regulations to be so important that it forces the entrepreneurs who cannot afford it to seek refuge in the informal sector. Regarding this, [3] considered that corruption can be viewed as an additional tax that increases the burden of regulation and drives entrepreneurs to operate in the informal economy. Using a tax collection model that puts together a taxpayer and potentially corruptible tax inspector, [6] emphasized the effect of regulation on corruption and showed a positive correlation between regulatory intensity (measured by the regulation of entry), corruption, and the size of the unofficial economy. Davis 
and Henerikson [13] found similar results. They performed an ordinary least squares (OLS) regression to estimate the effect of taxes on work activity, industry mix, and the size of the shadow economy; and they found that high tax rates lead to an increased underground economy. The results of the research done by [8] indicated that a high level of taxation, labor market regulation, corruption, and lack of good governance are the major determinants of the informal economy.

More recently, [11] used a structural equation model with two latent variables to examine the relationship between corruption and the shadow economy for a sample of 51 countries over the period from 2000 to 2005 and found a positive relationship. Using data for 69 countries to investigate factors that drive entrepreneurs in the unofficial economy, [5] found a positive relationship between corruption and the informal economy. They pointed out that the tax rate per se does not determine the decision to enter the informal economy. Rather, the burden of bureaucracy, corruption, and legal environment better explain the level of the unofficial economy.

Dreher and Schneider [10] used an OLS procedure to analyze the causal direction between corruption and the shadow economy for 98 developed and developing countries, with conflicting results. As a measure of corruption, they employed an index of corruption derived from a structural model and perceptions-based indices alternatively. They find that the results depend on the type of index used and on the level of development. Finally, while perception-based indices yield no robust relationship, structural model-based indices indicate that corruption and the informal economy are complementary for developing countries but not in developed countries.

Even though these recent studies establish complementarity between corruption and the informal economy, they implicitly show that the idea of a negative relationship can be conceived. Indeed, if the firm's fixed costs determine its ability to pay, only the high-return and high-profit firms will remain on the formal market. As these companies become fewer and fewer, they can force public servants to demand less bribes or lower their claims so as not to further deter an entrepreneur's willingness to remain in the formal sector. This would reduce corruption. It is this approach that [7] proposed to analyze the role of the informal economy in a context of corruption. According to their analysis, the existence of the informal economy mitigates corruption capacities of civil servants and thus is an enhancement of the official sector. Dreher et al. [9] demonstrated similar results by performing three-stage least squares (3SLS) regressions with data from 78 to 135 countries. They found that corruption and shadow markets are substitutes.

Several studies highlighted the role of the quality of institutional settings and regulation in explaining the informal economy. For example, [8] found that institutional quality (captured by rule of law, corruption, and business regulation) affects the informal economy. Dreher and Schneider [10] found that institutional quality is one of the major determinants of the size of the shadow economy. They stated that better institutional quality increases the benefits that entrepre- 
neurs operating in the formal sector derive from their activities. This in turn increases the incentive to remain in the formal economy. Moreover, good institutions lead to a lower level of corruption and a reduction in the size of the informal economy. This finding was also the conclusion reached by [9]. Their study found that institutional quality has a negative and significant effect on corruption and the shadow economy. Torgler and Schneider [14], after controlling for a variety of potential factors, found that higher institutional quality leads to a smaller size of the informal economy. Enste [15] built a regulatory index to analyze the relationship between regulations and the size of the shadow economy in 25 Organisation for Economic Co-operation and Development (OECD) countries. He found that the labor market, product regulation, general regulation, and poor quality of institutions and administration lead to a rise of the unofficial economy.

\section{Methodology}

As stated above, the objective of this study is to find the determinants of the informal economy in SSA. For this purpose, the basic specification on which we start is the one adopted by Dreher et al. (2008) [9] which expresses the underground economy in terms of institutional and control variables ${ }^{2}$. This model is expressed as follows:

$$
\text { Shadow }_{i}=\beta_{1}+\beta_{2} g_{i}+\beta_{3} Z_{i}+\varepsilon_{i}
$$

where $g_{i}$ stands for a vector of institutional variables for country $i$ and $Z_{i}$ stands for a vector of control variables. This equation will be used to specify our empirical model. Data from 23 Sub-Saharan African countries over the period from 1999 to -2007 will be used to conduct the empirical investigation.

\subsection{Variable Specification and Data Sources}

Besides corruption and the size of the informal economy, variables used in this study for estimations are mostly variables related to governance and institutional quality as well as socio-economic variables that can influence corruption and the informal economy. The size of the informal economy, the endogenous variable of the model, is not generally recorded in official statistics for a long period. Most often, authors estimate it. For this study, data computed by [16] are used. Corruption is measured through the corruption index provided by the International Country Risk Guide (ICRG, 2012) [17]. This index displays corruption scores ranging from 0 to 6 , where 0 designates a very high level of corruption and 6 a level of zero corruption. The other variables are related to economic and political governance and unemployment. Detailed definitions of the variables are provided in Table $\mathrm{A} 1$ in the appendix.

Economic governance is measured here by a composite index derived from 10 indicators of economic freedom (Overall Score, Property Rights, Freedom from

${ }^{2}$ This specification is the most commonly used in empirical tests for estimating the determinants of the informal economy. 
Corruption, Fiscal Freedom, Government Spending, Business Freedom, Monetary Freedom, Trade Freedom, Investment Freedom, Financial Freedom). These indicators come from the Heritage Foundation database, 2016 [18]. To calculate this composite indicator, we carried out a principal component analysis, which provided the main components of which the best explanation for the total variance of the sample was used for the construction of our indicator ${ }^{3}$. Sociopolitical stability (or quality of political governance) is introduced to reflect the influence of political and social factors on the informal economy. This variable is also a synthetic index composed of 11 indicators of governance and sociopolitical stability provided by the ICRG (2012) [17] . These indicators include Government Stability, Socioeconomic Conditions, Investment Profile, Internal Conflict, External Conflict, Military in Politics, Religion in Politics, Law and Order, Ethnic Tensions, Democratic Accountability, Bureaucracy Quality. The unemployment rate refers to the number of unemployed persons as a percentage of the total workforce. It is provided by labor statistics of the International Labor Office [19]. This variable has been widely identified as influencing the informal economy. The underlying argument is that a higher unemployment rate is associated with a larger informal economy.

Income and good governance indicators are also considered important factors that explain the size of the informal economy. In this study, national income is estimated by gross domestic product (GDP) per capita. The data are extracted from the world development indicators (WDI, 2015) [20]. Regarding the indicators of good governance, the six indicators identified by the World Bank as reflecting the state of governance in the country are used: voice and accountability (VA), political instability and violence (PIV), government effectiveness (GE), rule of law (ROL), control of corruption (COC), and regulatory quality (RQ). Thus, data on these variables come from worldwide governance indicators (WGI, 2015) [21]. Considering all these variables, our empirical model is the following:

$$
\begin{aligned}
\text { size }_{i t}= & \beta_{0}+\beta_{1} \text { corruption }_{i t}+\beta_{2} \text { governance }_{i t}+\beta_{3} \text { economic_freedom }_{i t} \\
& +\beta_{4} \text { unemployment }_{i t}+\beta_{5} \mathrm{GDP}_{-} \text {percapita }_{i t}+\beta_{6} \mathrm{VA}_{i t}+\beta_{7} \mathrm{PIV}_{i t} \\
& +\beta_{8} \mathrm{GE}_{i t}+\beta_{9} \mathrm{ROL}_{i t}+\beta_{10} \mathrm{COC}_{i t}+\beta_{11} \mathrm{RQ}_{i t}+\varepsilon_{i t}
\end{aligned}
$$

\subsection{Estimation Technique}

An OLS procedure is adopted to conduct econometric analyses. Most of our explanatory variables are related to the state of governance and are calculated ac-

\footnotetext{
${ }^{3}$ The variable economic freedom is expressed as a linear combination of the relative contribution of each of the 10 indicators to the formation of the main component: Economic freedom $=0.097^{\star}$ overall score $-0.138^{\star}$ property rights $-0.289^{\star}$ freedom from corruption $+0.571^{\star}$ fiscal freedom + $0.062^{\star}$ government spending $-0.368^{\star}$ business freedom $+0.099^{\star}$ monetary freedom $+0.532^{\star}$ trade freedom $+0.175^{\star}$ investment freedom $-0.019^{\star}$ financial freedom.

${ }^{4}$ The principal component analysis is applied and yields the following expression: Governance $=$ $0.752^{\star}$ Government Stability $+0.530^{\star}$ Socioeconomic Conditions $-0.024^{\star}$ Investment Profile $-0.019^{\star}$ Internal Conflict $-0.103^{\star}$ External Conflict $-0.429^{\star}$ Military in Politics $+0.382^{\star}$ Religion in Politics + $0.011^{\star}$ Law and Order $-0.207^{\star}$ Ethnic Tensions $-0.539^{\star}$ Democratic Accountability $-0.213^{\star} \mathrm{Bu}-$ reaucracy Quality.
} 
cording to the sociopolitical environment; thus, we can cast doubt on the absence of multicollinearity between these variables.

In this respect, it makes sense to retain for the analysis only one of the explanatory variables among those that are correlated with each other and which most often translate the same reality [22]. However, this procedure would require several tests, such as multicollinearity tests, to detect the correlated variables and make a subjective choice between one or the other variable. Thus, to remedy these concerns while realizing our objective of detecting the determinants of the informal economy in SSA, we estimate our empirical model using the stepwise regression method ${ }^{5}$. Indeed, in its conception, this method estimates several models by introducing the variables one by one to retain in the end the model containing the most significant explanatory variables and the least correlated ones. In this sense, this estimation technique seems appropriate for determining the variables that most influence the informal economy in SSA and the direction of these influences. This procedure has been applied using data for the 23 SSA countries displayed in Table 1.

\section{Empirical Results}

The estimation using the stepwise regression procedure leads us to estimate four different models to perceive the influences of isolated variables on the informal economy. First, the regression of our basic model (Column 2 of Table 2) shows that the coefficient assigned to the corruption index has a negative and significant sign, which means that an increase in this index leads to a decrease of the informal economy. As the increase in this index is associated with a relative decrease in the level of corruption in the country, this negative coefficient implies that the decline in the level of corruption is associated with a decrease in the contribution of the informal sector to the formation of GDP. Thus, the assumption that greater corruption leads to a larger share of the informal economy in GDP is verified. It appears that in SSA, corruption is a factor favoring the expansion of the informal sector. This result is in accordance with those of [5] [9] and

Table 1. List of countries in the sample.

\begin{tabular}{lll}
\hline 1-Bissau Guinea & 9 -Guinea & $17-$ Nigeria \\
2-Botswana & $10-$ Kenya & 18 -Senegal \\
3-Burkina Faso & $11-$ Madagascar & $19-$ South Africa \\
4-Cameroun & $12-$ Malawi & $20-$ The Gambia \\
5-Congo Republic & $13-$ Mali & $21-$ Togo \\
6-Côte d'Ivoire & $14-$ Mozambique & $22-$ Zambia \\
7-Gabon & $15-$ Namibia & $23-$ Zimbabwe \\
8-Ghana & $16-$ Niger & \\
\hline
\end{tabular}

${ }^{5}$ To perform the stepwise regression EViews was used. 
Table 2. Results of the estimations.

\begin{tabular}{|c|c|c|c|c|}
\hline & Basic Model & $\begin{array}{l}\text { Model 2: } \\
\text { Economic } \\
\text { Freedom } \\
\text { Indicators }\end{array}$ & $\begin{array}{l}\text { Model 3: } \\
\text { Sociopolitical } \\
\text { Stability } \\
\text { Indicators }\end{array}$ & $\begin{array}{l}\text { Model 4: } \\
\text { No Composite } \\
\text { Indicators }\end{array}$ \\
\hline Corruption & $\begin{array}{l}-1.175500^{* *} \\
(0.0209)\end{array}$ & $\begin{array}{l}-0.779521 \\
(0.1489)\end{array}$ & $\begin{array}{l}-0.775504^{*} \\
(0.0549)\end{array}$ & $\begin{array}{l}-1.110536^{* *} \\
(0.0125)\end{array}$ \\
\hline Governance & $\begin{array}{l}-0.635739^{* * *} \\
(0.0036)\end{array}$ & & & \\
\hline Economic freedom & $\begin{array}{l}-0.062631 \\
(0.1302)\end{array}$ & & & \\
\hline Unemployment & $\begin{array}{l}-0.412023^{* * *} \\
(0.0031)\end{array}$ & $\begin{array}{l}-0.562410^{* * *} \\
(0.0001)\end{array}$ & $\begin{array}{l}-0.562549^{* * *} \\
(0.0000)\end{array}$ & $\begin{array}{l}-0.573386^{* * *} \\
(0.0000)\end{array}$ \\
\hline GDP per capita & $\begin{array}{l}0.000702^{* * *} \\
(0.0005)\end{array}$ & $\begin{array}{l}0.000865^{* * *} \\
(0.0000)\end{array}$ & $\begin{array}{l}0.000798^{* * *} \\
(0.0000)\end{array}$ & $\begin{array}{l}0.000767^{* * *} \\
(0.0000)\end{array}$ \\
\hline $\begin{array}{l}\text { Voice and } \\
\text { accountability }\end{array}$ & & & $\begin{array}{l}0.096496^{*} \\
(0.0717)\end{array}$ & $\begin{array}{l}0.041436 \\
(0.4438)\end{array}$ \\
\hline $\begin{array}{l}\text { Political stability } \\
\text { and violence }\end{array}$ & $\begin{array}{l}-0.086278^{\star *} \\
(0.0149)\end{array}$ & $\begin{array}{l}-0.113066^{\star * *} \\
(0.0007)\end{array}$ & & $\begin{array}{l}-0.026501 \\
(0.4455)\end{array}$ \\
\hline $\begin{array}{l}\text { Government } \\
\text { effectiveness }\end{array}$ & $\begin{array}{l}-0.026595 \\
(0.5839)\end{array}$ & $\begin{array}{l}-0.225570^{* * *} \\
(0.0000)\end{array}$ & $\begin{array}{l}-0.038733 \\
(0.4372)\end{array}$ & \\
\hline Rule of law) & $\begin{array}{l}0.272706^{* * *} \\
(0.0000)\end{array}$ & $\begin{array}{l}0.255118^{* * *} \\
(0.0000)\end{array}$ & $\begin{array}{l}0.123954^{* * *} \\
(0.0037)\end{array}$ & $\begin{array}{l}0.144857^{* * *} \\
(0.0076)\end{array}$ \\
\hline $\begin{array}{l}\text { Control of } \\
\text { corruption }\end{array}$ & & $\begin{array}{l}-0.052219 \\
(0.2918)\end{array}$ & $\begin{array}{l}-0.040289 \\
(0.3739)\end{array}$ & $\begin{array}{l}-0.037577 \\
(0.3754)\end{array}$ \\
\hline Regulatory quality & $\begin{array}{l}-0.391040^{\star * *} \\
(0.0000)\end{array}$ & & & $\begin{array}{l}-0.117210^{* *} \\
(0.0325)\end{array}$ \\
\hline Overall score & & $\begin{array}{l}-0.549061^{\star *} \\
(0.0180)\end{array}$ & & $\begin{array}{l}-0.329049^{* *} \\
(0.0227)\end{array}$ \\
\hline Property rights & & $\begin{array}{l}0.070449 \\
(0.1539)\end{array}$ & & $\begin{array}{l}0.089381^{\star *} \\
(0.0299)\end{array}$ \\
\hline $\begin{array}{l}\text { Freedom from } \\
\text { corruption }\end{array}$ & & & & $\begin{array}{l}0.107570^{* * *} \\
(0.0079)\end{array}$ \\
\hline Fiscal freedom & & $\begin{array}{l}0.106416^{\star \star} \\
(0.0419)\end{array}$ & & $\begin{array}{l}0.109747^{* * *} \\
(0.0059)\end{array}$ \\
\hline $\begin{array}{l}\text { Government } \\
\text { spending }\end{array}$ & & $\begin{array}{l}-0.050012 \\
(0.2569)\end{array}$ & & \\
\hline Business freedom & & $\begin{array}{l}0.116745^{\star *} \\
(0.0372)\end{array}$ & & $\begin{array}{l}0.077769^{\star} \\
(0.0900)\end{array}$ \\
\hline Monetary freedom & & $\begin{array}{l}-0.192445^{\star * *} \\
(0.0000)\end{array}$ & & \\
\hline Trade freedom & & & & $\begin{array}{l}0.024271 \\
(0.4569)\end{array}$ \\
\hline
\end{tabular}


Continued

\begin{tabular}{|c|c|c|c|c|}
\hline Investment freedom & & $\begin{array}{l}0.072822 \\
(0.1068)\end{array}$ & & $\begin{array}{l}0.099872^{* * *} \\
(0.0080)\end{array}$ \\
\hline Financial freedom & & $\begin{array}{l}0.073181 \\
(0.1503)\end{array}$ & & \\
\hline $\begin{array}{l}\text { Government } \\
\text { stability }\end{array}$ & & & $\begin{array}{l}0.376301 \\
(0.2126)\end{array}$ & $\begin{array}{l}0.325123 \\
(0.2685)\end{array}$ \\
\hline $\begin{array}{l}\text { Socio-economic } \\
\text { conditions }\end{array}$ & & & $\begin{array}{l}-1.695799^{* * *} \\
(0.0000)\end{array}$ & $\begin{array}{l}-1.443906^{* * *} \\
(0.0007)\end{array}$ \\
\hline Investment profile & & & $\begin{array}{l}-2.599799^{* * *} \\
(0.0000)\end{array}$ & $\begin{array}{l}-2.100186^{* * *} \\
(0.0000)\end{array}$ \\
\hline Internal conflict & & & $\begin{array}{l}-1.133595^{\star * *} \\
(0.0001)\end{array}$ & $\begin{array}{l}-0.814511^{* *} \\
(0.0460)\end{array}$ \\
\hline External conflict & & & $\begin{array}{l}0.616557^{\star *} \\
(0.0420)\end{array}$ & $\begin{array}{l}0.521186^{*} \\
(0.0879)\end{array}$ \\
\hline Military in politics & & & $\begin{array}{l}-0.958477^{\star * *} \\
(0.0022)\end{array}$ & $\begin{array}{l}-1.140314^{\star * *} \\
(0.0009)\end{array}$ \\
\hline Religion in politics & & & $\begin{array}{l}-0.807621^{* * *} \\
(0.0075)\end{array}$ & $\begin{array}{l}-0.864875^{* * *} \\
(0.0079)\end{array}$ \\
\hline Law and order & & & $\begin{array}{l}0.955669^{*} \\
(0.0589)\end{array}$ & $\begin{array}{l}0.671216 \\
(0.2131)\end{array}$ \\
\hline Ethnic tensions & & & $\begin{array}{l}2.875480^{* * *} \\
(0.0000)\end{array}$ & $\begin{array}{l}2.785292^{* * *} \\
(0.0000)\end{array}$ \\
\hline $\begin{array}{l}\text { Democratic } \\
\text { accountability }\end{array}$ & & & $\begin{array}{l}-0.467545 \\
(0.2788)\end{array}$ & $\begin{array}{l}-0.424467 \\
(0.3183)\end{array}$ \\
\hline Bureaucracy quality & & & $\begin{array}{l}0.777981 \\
(0.1876)\end{array}$ & $\begin{array}{l}-0.512620 \\
(0.4243)\end{array}$ \\
\hline Constant & $\begin{array}{l}61.03708^{\star * *} \\
(0.0000)\end{array}$ & $\begin{array}{l}74.49107^{* * *} \\
(0.0000)\end{array}$ & $\begin{array}{l}61.25609^{* * *} \\
(0.0000)\end{array}$ & $\begin{array}{l}58.08776^{\star * \star} \\
(0.0000)\end{array}$ \\
\hline R-squared & 0.493375 & 0.581924 & 0.743636 & 0.780112 \\
\hline Adjusted R-squared & 0.470229 & 0.549091 & 0.719091 & 0.748351 \\
\hline F-statistic & 21.31639 & 17.72365 & 30.29628 & 24.56150 \\
\hline Prob. (F-statistic) & 0.000000 & 0.000000 & 0.000000 & 0.000000 \\
\hline
\end{tabular}

Note: $\mathrm{p}$-value in parentheses.

[11]. Moreover, this analysis is even more justified because the coefficient of governance is negative and significant, which explains why a better quality of political governance reduces the size of the informal economy. Thus, in agreement with the explanation given by [23], the low level of development of the SSA countries goes hand in hand with poor institutional quality, which, through fiscal incivism and corruption, increases the size of the informal economy. 
However, the influence of income levels on the size of the shadow economy is to be nuanced because the per capita income introduced in our basic model has a positive sign. This means that, in SSA, higher levels of income are associated with a greater contribution from the informal sector. This paradox is explained by the participation of the informal sector in the formation of national income. In developing countries, such as those of SSA, informal entrepreneurs do not evolve totally in the shadows because there are systems of taxation in the informal sector. In several African countries, informal enterprises pay direct and indirect taxes. Indeed, some countries, such as Burkina Faso and Niger, have set up a specific taxation system for the informal sector to bring informal enterprises to pay taxes. They also pay indirect taxes through the purchase of inputs that mostly come from the formal sector [24]. Thus, the informal economy contributes to the formation of the national income, and the larger it is, the greater its contribution. In addition, there is evidence that the informal economy also contributes to the reduction of the state's social burden by generating income for the workers of the informal economy. In this regard, it is recognized there is a positive relationship between per capita income and the size of the informal sector.

Regarding the relationship between the unemployment rate and the size of the informal economy, we find that the coefficient of the unemployment rate is negative and significant. This means that a fall in unemployment rates in SSA is associated with an increase in the size of the informal sector. This negative relationship reflects the fact that, in SSA countries where social conditions are not very good, the supply of informal goods and services comes mainly from skilled or unskilled labor that did not find employment in the formal economy. Thus, informal activities, while generating income, also decrease the proportion of the unemployed in the country.

As for the other variables, the estimation of our basic model shows that, in addition to the corruption index, the quality of political governance, per capita income, and the unemployment rate, indicators of good governance, such as political stability, the rule of law, and the quality of regulation, have significant effects on the size of the informal economy in SSA. However, contrary to the analysis of [4], economic freedom appears to have no significant effect on the informal economy. However, assuming that this result can be linked to an econometric bias arising from the fact that this variable is introduced as a composite indicator, we estimate a model in which the indicators of economic freedom are introduced as regressors. The results of this estimation (Column 3 of Table 2) show that, among the indicators of economic freedom, fiscal freedom, business freedom, and monetary freedom have significant effects on the informal economy. Thus, greater fiscal freedom and business freedom are associated with a larger informal economy, while monetary freedom reduces this size.

To identify the indicators of the quality of political institutions that best explain the evolution of the informal economy in SSA, we estimate a model with decomposed indicators. From this estimate (Column 4 of Table 2), it appears that only government stability, democratic accountability, and bureaucracy 
quality have no significant effect on the informal economy. However, this estimate also provides information on the variables that determine the influence of the quality of political institutions on the informal economy. The results show that 1) less socio-economic pressures promote greater effectiveness of political institutions, which reduces the size of the informal economy; 2) lower risk of loss of investment due to political, economic, and financial factors increases entrepreneurs' confidence in political institutions and thus reduces the size of the informal economy; 3) less political and civil violence leads to a better quality of governance and a decrease in informal activities; and 4) a low risk of external conflict (i.e., less external diplomatic or commercial pressure) is associated with a larger informal economy; 5) the less the military is involved in the management of political affairs, the more effective the government policy and the smaller the informal economy; and 6) lesser social tensions are associated with a better quality of political institutions and a decline in the size of the informal economy.

Moreover, the estimation of a fourth model containing all variables confirms the effects of the variables identified in the other three models as determinants of the size of the informal economy in SSA but suggests others that appear to have effects on the unofficial economy. These include property rights, freedom from corrupt, and investment freedom.

\section{Conclusions}

This study was aimed at determining the relationship between governance, corruption, and the size of the informal economy in SSA. An OLS regression was applied on the data of 23 countries. The results show that a high level of corruption and poor institutional settings favor an increase of the informal economy. There is also evidence that the unemployment rate is negatively related to the size of the informal economy and that greater fiscal freedom and greater business freedom are associated with a larger informal economy, while monetary freedom reduces the size.

From a policy point of view, the results suggest that the burden of institutional setting, governance, and corruption can lead entrepreneurs to enter to the informal economy. The findings also show that the informal economy is an important component of the economy. For this reason, it must be considered when implementing economic policies. Thus, it is necessary for any action aimed at using this sector to enhance growth to tackle the conducive factors of the informal economy identified in this study.

Despite these findings, the model suffers from the lack of a variable reflecting the burden of taxation (corporate and income taxes) which is considered as an important factor that causes the emergence and the spread of the informal economy. Including such a variable in the model could provide a better understanding of the role of taxation in the entrepreneurs' decision to flee to the informal economy. The use of alternative data (country-specific data) for the size of the informal sector to test the robustness of the results is also likely to im- 
prove the results of the study.

\section{Acknowledgements}

I am very grateful to Ouattara Yaya Ben Yaya for his invaluable contribution to this paper.

\section{References}

[1] De Soto, H. (1989) The Other Path. Harper and Row Publishers Inc., New York.

[2] La Porta, R. and Schleifer, A. (2011) The Unofficial Economy in Africa. NBER Working Paper, 16821. https://doi.org/10.3386/w16821

[3] Johnson, S., Kaufmann, D. and Shleifer, A. (1997) The Unofficial Economy in Transition. Brookings Papers on Economic Activity, Fall, Washington D.C.

[4] Johnson, S., Kaufmann, D. and Zoido-Lobatón P. (1998) Corruption, Public Finances and the Unofficial Economy. World Bank Policy Research Working Paper Series, No. 2169. The World Bank, Washington, D.C.

[5] Friedman, E., Johnson, S., Kaufmann, D. and Zoido-Lobaton, P. (2000) Dodging the Grabbing Hand: The Determinants of Unofficial Activity in 69 Countries. Journal of Public Economics, 76, 459-493. https://doi.org/10.1016/S0047-2727(99)00093-6

[6] Djankov, S., La Porta, R., Lopez-de-Silanes, F. and Shleifer, A. (2002) The Regulation of Entry. The Quarterly Journal of Economics, 117, 1-37. https://doi.org/10.1162/003355302753399436

[7] Choi, J.P. and Thum, M. (2005) Corruption and the Shadow Economy. International Economic Review, 46, 817-836. https://doi.org/10.1111/j.1468-2354.2005.00347.x

[8] Chowdhury, H.U. (2005) Informal Economy, Governance, and Corruption. Philippine Journal of Development, XXXII, 103-134.

[9] Dreher, A., Kotsogiannis, C. and McCorriston, S. (2009) How Do Institutions Affect Corruption and the Shadow Economy? International Tax and Public Finance, 16, 773-796. https://doi.org/10.1007/s10797-008-9089-5

[10] Dreher, A. and Schneider, F. (2010) Corruption and the Shadow Economy: An Empirical Analysis. Public Choice, 144, 215-238. https://doi.org/10.1007/s11127-009-9513-0

[11] Beuhn, A. and Schneider, F. (2012) Corruption and the Shadow Economy: Like Oil and Vinegar, Like Water and Fire? International Tax and Public Finance, 19, 172 194. https://doi.org/10.1007/s10797-011-9175-y

[12] Shleifer, A. and Vishny, R.W. (1993) Corruption. The Quarterly Journal of Economics, 108, 599-617. https://doi.org/10.2307/2118402

[13] Davis, S.J. and Henrekson, M. (2004) Tax Effects in Work Activity, Industry Mix and Shadow Economy Size: Evidence from Rich-Country Comparisons. NBER Working Paper No. 10509. http://www.nber.org/papers/w10509 https://doi.org/10.3386/w10509

[14] Torgler, B. and Schneider, F. (2009) The Impact of Tax Morale and Institutional Quality on the Shadow Economy. Journal of Economic Psychology, 30, 228-245. https://doi.org/10.1016/j.joep.2008.08.004

[15] Enste, D.H. (2010) Shadow Economy-The Impact of Regulation in OECD- Counties. International Economic Journal, 24, 555-571.

[16] Schneider, F., Buehn, A. and Montenegro, C.E. (2010) Shadow Economies All over the World: New Estimates for 162 Countries from 1999 to 2007. Policy Research 
Working Paper 5356, The World Bank, Washington DC.

http://www.econ.jku.at/members/Schneider/files/publications/LatestResearch2010/ SHADOWECONOMIES June8 2010 FinalVersion.pdf

[17] International Country Risk Guide (ICRG) (2012) Researchers International Country Risk Guide (ICRG) Researchers Dataset 2013-05-132016 Harvard. https://dataverse.harvard.edu/dataset.xhtml?persistentId=hdl:1902.1/21446

[18] Heritage Foundation (2016) Index of Economic Freedom. http://www.heritage.org/index/download http://www.heritage.org/index/book/methodology

[19] ILO (2015) Key Indicators of the Labour Market (KILM). http://www.ilo.org/global/statistics-and-databases/research-and-databases/kilm/lan g--en/index.htm

[20] World Bank (2015) World Development Indicators. http://data.worldbank.org/data-catalog/world-development-indicators

[21] World Bank (2015) Worldwide Governance Indicators. http://info.worldbank.org/governance/wgi/index.aspx\#home

[22] De Bourmont, M. (2012) La Résolution d'un Problème de Multicolinéarité au Sein des Etudes Portant sur les Déterminants d'une Publication Volontaire d'Informations: Proposition d'un Algorithme de Décision Simplifié Basé sur les Indicateurs de Belsley, Kuh et Welsch (1980). In: Comptabilités et innovation, Grénoble, cd-rom.

[23] Schneider, F. and Enste, D.H. (2000) Shadow Economies: Size, Causes, and Consequences. Journal of Economic Literature, 38, 77-114.

https://doi.org/10.1257/jel.38.1.77

[24] Gautier, J.F., Rakotomanana, F. and Roubaud, F. (2001) La Fiscalisation du Secteur Informel: Recherche impôt Désespérément. Revue Tiers Monde, 42, 795-815. https://doi.org/10.3406/tiers.2001.1550 


\section{Appendix}

Table A1. Variables definition and sources.

\begin{tabular}{ll}
\hline Variable Definition & Source \\
\hline
\end{tabular}

Size

Corruption

Governance

Economic_freedom

Unemployment

Political_stability_and_violence (PIV)

Rule_of_law (ROL)

Control_of_corruption (COC)

Regulatory_quality (RQ)
GDP_percapita

Voice_and_accountability (VA)

Expresses the share of the informal economy in the GDP. It is calculated according to the Multiple Indicators Multiple Causes (MIMIC) econometric method. An increase in this variable also reflects a relatively larger size of the informal sector in the country.

Measurement of corruption in the governance system, particularly in terms of bribes and special and unusual payments met by businesses. Corruption scores range from 0 to 6 , with 0 designating a very high level of corruption and 6 a level of zero corruption.

This is a composite index of the quality and stability of political institutions. It is calculated on the basis of the main component analysis of the main indicators of quality of the political institutions of the ICRG (2012). By construction, an increase in this variable indicates a better quality of political governance.

Composite indicator of economic freedom calculated from the principal components analysis of the economic freedom variables of the Heritage Foundation base (2016). An increase in this variable reflects more economic freedom, thus less economic and financial regulation

Measure of the unemployment rate, i.e. the share of the non-employed labor force in the total labor force.

It is a measure of national income divided by the number of people in the country. By construction, the larger this variable, the higher the level of development of the country.

Measurement of freedom of expression and inclusion of citizens in the decision-making process and governance system. The larger it is, the more inclusive development and governance strategies are, which increases their effectiveness

Evaluates the risk of violence and abrupt and unexpected change in government. The higher the score the lower the risk and therefore the better the quality of governance.

Translates the effectiveness of government in the conduct of public

Government_effectiveness (GE) affairs and the quality of public service. A more effective government has a better score

Measures trust and respect for political and judicial institutions by citizens. A higher score is associated with better respect for the rule of law

It expresses the extent to which public action related to the rules and functioning of public administration promotes corruption. Higher ranking is given to countries with better control of corruption

It is the measure of the quality of governance in the sense of enabling an environment conducive to the development of the private sector. Higher ranking is given to countries with better regulation
Schneider et al. (2010)

International Country Risk

Guide (ICRG, 2012)

Calculated by the author, using data from ICRG (2012)

Calculated by the author, using data from Heritage Fundation (2016)

International Labor Office

World Development Indicators (WDI, 2015)

World Governance Indicators (WGI, 2015)

World Governance Indicators (WGI, 2015)

World Governance Indicators (WGI, 2015)

World Governance Indicators (WGI, 2015)

World Governance Indicators (WGI, 2015)

World Governance Indicators (WGI, 2015) 


\section{Continued}

Property_rights

Freedom_from_corruption

Fiscal_freedom

Government_spending

Business_freedom

Monetary_freedom

Trade_freedom

Investment_freedom

Financial_freedom

Government_stability

Socioeconomic_conditions

Investment_profile

Internal_conflict
This indicator measures the degree to which private property rights is respected in the economy. It also reflects the extent to which the judicial system is independent. A higher score expresses more legal protection of property.

Evaluates the extent to which government regulation and the operating principles of public administrations foster an environment of corruption in the business climate.

It is a measurement of tax burden derived from government taxation. The lower the tax burden, the greater the incentive for entrepreneurs to invest.

Evaluates the extent to which government spending influences the business environment whether in terms of eviction or distortions in the functioning of the economy. To this end, excessive expenditure is akin to a reduction in economic freedoms.

This variable reflects the freedom to create and operate a business. It reflects the extent to which public regulation and the business environment affect entrepreneurship. Thus, more business freedom should facilitate the creation of formal enterprises.

It is an indicator of price stability and control, which promotes a certain security in terms of preserving the value of investments and wealth. A high value of this variable reflects a more stable monetary policy.

It reflects the extent to which the opening of the local economy to the international market is not constrained by public regulation, particularly in terms of trade taxation and non-tariff barriers. It is especially important for companies with a broad development plan but is an important indicator of the freedom of foreign trade

Measures freedom of investment, particularly in terms of creating opportunities, facilitating research and development, and free movement of capital. More investment freedom favors the creation of companies

Measures the accessibility and efficiency of the financial system, particularly with regard to credit, savings and payments.

Measures the ability of the government to effectively manage its projects and programs and remain in place. The higher the score, the more effective and stable the government

Measures the influence of social and economic pressures on the effectiveness of government. The higher it is, the less social governance constraints the governance and therefore the more effective it is

Indicates the risk of loss of investment due factor other than political, economic and financial risks. These factors include contract viability, profit repartition and payment delays. A high score (4) reflects a low risk and a low score $(0)$ reflects a high risk

It expresses the existence of civic and political violence and their ability to impede good governance. A high score (4) signifies an absence of armed or civil opposition against the government and that the latter does not exert violence on the population. At the extreme, a low score (0) reflects the existence of civil war in the country
Economic Freedom Heritage Fundation (2016)

Economic Freedom Heritage Fundation (2016)

Economic Freedom Heritage Fundation (2016)

Economic Freedom Heritage Fundation (2016)

Economic Freedom Heritage Fundation (2016)

Economic Freedom Heritage Fundation (2016)

Economic Freedom Heritage Fundation (2016)

Economic Freedom Heritage Fundation (2016)

Economic Freedom Heritage Fundation (2016)

International Country Risk Guide (ICRG, 2012)

International Country Risk Guide (ICRG, 2012)

International Country Risk Guide (ICRG, 2012)

International Country Risk Guide (ICRG, 2012) 


\section{Continued}

External_conflict

Military_in_politics

Religion_in_politics

Law_and_order

Ethnic_tensions

Democratic_accountability

Bureaucracy_quality
It assesses the risk of government pressure from outside, particularly in terms of diplomatic pressure or even border conflicts. A high value corresponds to a low risk while a low rating is a high risk

Translates the intervention of the army into politics. A military involvement in political management translates upstream or downstream a risk of flouting democratic rules. A low score reflects a high risk and vice versa

It expresses the risk of religious tensions linked to the fact that a religious group wants to replace civil rights by religious law.

It is an indicator of law and order that assesses the effectiveness and impartiality of the judicial system as well as the respect of the rules and laws by the populations. A low risk corresponds to a high score

It assesses the risk of tensions linked to racial and identity discrimination. The higher the score the lower the risk and the more stable the governance

It expresses the extent to which governments are responsive to the aspirations of the people, which reflects to a lesser extent the effectiveness of the governance system and its capacity to ensure a stable democratic regime. A high score corresponds to a low risk therefore a more effective democracy

It is a measure of the strength and expertise of government in defining and managing projects and programs so as to minimize radical changes to governance programs. High value translates into more effective government. Guide (ICRG, 2012)

International Country Risk Guide (ICRG, 2012)

International Country Risk Guide (ICRG, 2012)

International Country Risk Guide (ICRG, 2012) International Country Risk Guide (ICRG, 2012)

International Country Risk

Guide (ICRG, 2012)

International Country Risk

International Country Risk Guide (ICRG, 2012)
Submit or recommend next manuscript to SCIRP and we will provide best service for you:

Accepting pre-submission inquiries through Email, Facebook, LinkedIn, Twitter, etc. A wide selection of journals (inclusive of 9 subjects, more than 200 journals)

Providing 24-hour high-quality service

User-friendly online submission system

Fair and swift peer-review system

Efficient typesetting and proofreading procedure

Display of the result of downloads and visits, as well as the number of cited articles

Maximum dissemination of your research work

Submit your manuscript at: http://papersubmission.scirp.org/

Or contact me@scirp.org 